\title{
SEREHYBA SANCTISEBASTIANI N. GEN., N. SP. (HYDROZOA, TUBULARIIDAE), SYMBIONT OF A GORGONIAN OCTOCORAL FROM THE SOUTHEAST COAST OF BRAZIL
}

by

\author{
FÁBIO LANG DA SILVEIRA \\ Dept. de Zoologia da Universidade de São Paulo, Cx. Postal 20520, São Paulo, SP, 01498, Brazil
}

$\&$

ALVARO ESTEVES MIGOTTO

Centro de Biologia Marinha da Universidade de São Paulo, Cx. Postal 83, São Sebastião, SP, 11600, Brazil

\section{SUMMARY}

An athecate hydrozoan, Serehyba sanctisebastiani, representing a new genus, is described. It possesses gonosomes with a cormidium-like structure unique among tubulariids: a distal set of branched nematophores and a proximal gonodendron. $S$. sanctisebastiani is apparently transitional between the families Tubulariidae and Corymorphidae. It is a symbiont of the gorgonian octocoral Lophogorgia punicea (Milne Edwards \& Haime, 1857).

\section{RÉSUMÉ}

On décrit un Hydrozoaire athèque, Serehyba sanctisebastiani, représentant d'un genre nouveau. Celui-ci possède des gonosomes ayant une structure rappelant un cormidium et qui est unique parmi les Tubulariides: une garniture distale de nématophores ramifiés et un gonodendron proximal. $S$. sanctisebastiani fait apparemment la transition entre les familles des Tubulariidae et des Corymorphidae. C'est un symbionte de la Gorgone Lophogorgia punicea (Milne Edwards \& Haime, 1857).

\section{INTRODUCTION}

A new genus and species of an athecate hydroid of the family Tubulariidae Allman, 1864, was found near the Centro de Biologia Marinha da Universidade de São Paulo (CEBIMar-USP) on Jarobá Point and Baleeiro Point, at the south continental margin of São Sebastião Channel, State of São Paulo, Brazil. We have always found this hydroid to be epibiotic on Lophogorgia punicea (Milne Edwards \& Haime, 1857) (=Lophogorgia sp. indet. b Bayer, 1961: 212, text-fig. 64 d-f, pl. VII fig. 2).
The species is referable to a new genus, Serehyba, on the basis of a gonosome structure comparable to the siphosome of some Siphonophora: the gonosome is a "cormidium" including a "gonodendron" and a "siphon"; the gonophores are detached anthomedusae of the reduced symmetrical type and the nematophore (="siphon") is a "palpon". It differs from previously designated genera in the family according to Petersen (1979): from the solitary Tubularia Linnaeus, 1758, with a firm perisarc and from the solitary Zyzzysus Stechow, 1921, with a thin perisarc, by being colonial; and from the colonial Ectopleura L. Agassiz, 1862, by having radial canals in the hydranth and separate endodermis canals within parenchyma in the hydrocaulus.

Hydroid polyps of the family Tubulariidae are poorly known from the southeast coast of Brazil. The only record is of the hydranth of the medusa of Ectopleura dumortieri (Van Beneden, 1844) from the lagoon region of Cananéia, State of São Paulo, Brazil (Vannuci, 1957).

\section{DESCRIPTION}

Serehyba sanctisebastiani n. gen., n. sp.

(Figs. 1-4)

Material examined. - Brazil, State of São Paulo, São Sebastião, Jarobá and Baleeiro Points $\left(20^{\circ} 45^{\circ} 42^{\prime \prime} \mathrm{S}\right.$ $45^{\circ} 26^{\prime} 30^{\sim} \mathrm{W}$ ), 10 July $1981,5 \mathrm{~m}, 1$ hydranth, F. L. da Silveira coll.; 28 August 1981, 5 m, 1 hydranth, F. L. da 
Silveira coll.; 19 September 1982, 3.5 m, 4 hydranths, F. L. da Silveira coll.; 4 November 1982, 4 m, 11 hydranths, A. E. Migotto coll.

In the laboratory, specimens were maintained in aquaria at water temperatures varying between 22 and $28^{\circ} \mathrm{C}$. The hydranths were fed daily with fresh nearshore plankton organisms captured by a hand-towed plankton net $(60 \mu \mathrm{m}$ mesh). All gross anatomy measurements were done with fixed and preserved animals. Living colors are referred to color charts in "Atlas de los Colores" (Küppers, 1979). The nomenclature employed for nematocysts is that of Weill (1937) and Millard (1975). Histological examinations of trophosomes and gonosomes were done with specimens fixed in Bouin's and Heidenhain's fixatives. Histological examinations of free medusae were done with specimens fixed in formalin. Sections were stained with Mallory Tricromic after counterstaining cell nuclei with Weigert's Hematoxylin (Mahoney, 1973). Mean surface water temperature at Jarobá Point was $24^{\circ} \mathrm{C}\left(\max .28^{\circ} \mathrm{C}\right.$; $\min .20^{\circ} \mathrm{C}$ ) and salinity ranged from 31 to $34 \%$ for the period March 1981 - February 1983.

Holotype: MZUSP-479, Museu de Zoologia da Universidade de São Paulo, Brazil, State of São Paulo, São Sebastião, Jarobá Point $\left(20^{\circ} 45^{\circ} 42^{\prime} \mathrm{S} 45^{\circ} 26^{\prime} 30^{\circ} \mathrm{W}\right), 4$ November 1982, 4 m, 1 hydranth and part of Lophogorgia punicea (Milne Edwards Haime, 1857), A. E. Migotto coll.

Paratypes: MZUSP-478, 19 September 1982, $4 \mathrm{~m}, 1$ female hydranth, F. L. da Silveira coll.; MZUSP-480, 4 November 1982, $4 \mathrm{~m}$, longitudinal sections in histological preparations, 1 female hydranth, A. E. Migotto coll.; furthermore, five paratypes are deposited in the Zoölogisch Museum, Amsterdam, coll. no. ZMA Coel. 8375-8376.

Diagnosis: - Trophosome solitary or colonial, without rooting processes. Hydrocaulus with firm perisarc, the central space filled with parenchyma and with longitudinal separate endodermal canals. Modular construction of gonosome in cormidium including gonodendron and palpon. Gonophores released as freeswimming reduced medusae. Medusae radially symmetrical, with four radial canals and ring canal, without tentacles or tentacle buds and without nematocysts in the exumbrella.

Etymology: - The genus name is derived from Tupi, the language of the Brazilian Indians, meaning "mangrove-tree"' (ciri $=$ crab; $\mathrm{yba}=$ tree) and is transformed into the nominative singular of a Latin feminine noun. The specific name is derived from São
Sebastião, the geographic designation of the study area, and is transformed into the genitive singular of a Latin masculin noun.

\section{GENERAL FEATURES OF COLONIES (TROPHO- SOMES)}

A comprehensive account of quantitative data from several animals is summarized in table I. The hydrozoan grows closely attached to its gorgonian host by means of a hydrocaulus extension which is next to the axis skeleton and under the coenenchyme of the gorgonian. The hydrozoan projects outward and off the host. One of the largest animals had a total hydrocaulus length of $150 \mathrm{~mm}$, of which $95 \mathrm{~mm}$ was invested with gorgonian coenenchyme.

\section{TABLE I}

Morphological character variation of Serehyba sanctisebastiani n. gen., n. sp., based on measurements of twelve animals. Immature forms $=$ hydranths without well-formed medusae; mature forms = hydranths with well-formed medusae.

Immature forms Mature forms

average (range) average (range)

\begin{tabular}{|c|c|c|}
\hline \multicolumn{3}{|l|}{ Hydrocauli } \\
\hline diameter (mm) & $0.9(0.7-1.0)$ & $1.5(1.0-2.0)$ \\
\hline number of canals ${ }^{*}$ & $10(9-11)$ & $10(10-11)$ \\
\hline neck length (mm) & $1.5(0.7-2.0)$ & $4.0(1.0-7.5)$ \\
\hline \multicolumn{3}{|l|}{ Hydranths } \\
\hline diameter $(\mathrm{mm})^{* *}$ & $2.0(1.7-2.4)$ & $4.0(2.5-5.0)$ \\
\hline length $(\mathrm{mm})^{* * *}$ & $3.0(2.0-4.0)$ & $6.0(4.0-9.0)$ \\
\hline \multicolumn{3}{|l|}{ Tentacles } \\
\hline \multicolumn{3}{|l|}{ aboral ( = proximal) } \\
\hline number & $26(18-27)$ & $30(28-34)$ \\
\hline length (mm) & $5.0(4.0-6.0)$ & $15.0(6.0-20.0)$ \\
\hline \multicolumn{3}{|l|}{ oral (= distal) } \\
\hline number & $44(34-48)$ & $60(55-71)$ \\
\hline length (mm) & $1.2(1.0-1.5)$ & $2.0(1.5-4.0)$ \\
\hline \multicolumn{3}{|l|}{ Gonosomes } \\
\hline number & $11(8-13)$ & $11(8-16)$ \\
\hline length (mm) & $0.5(0.3-0.6)$ & $3.5(2.5-5.0)$ \\
\hline \multicolumn{3}{|l|}{ Medusae } \\
\hline length (mm) & - & $1.1(1.0-1.2)$ \\
\hline diameter (mm) & 一 & $0.85(0.8-0.9)$ \\
\hline
\end{tabular}

- at about $50 \mathrm{~mm}$ from the base of the hydranth

** at the level of the aboral tentacles

*** from the base to the top of the hypostome 


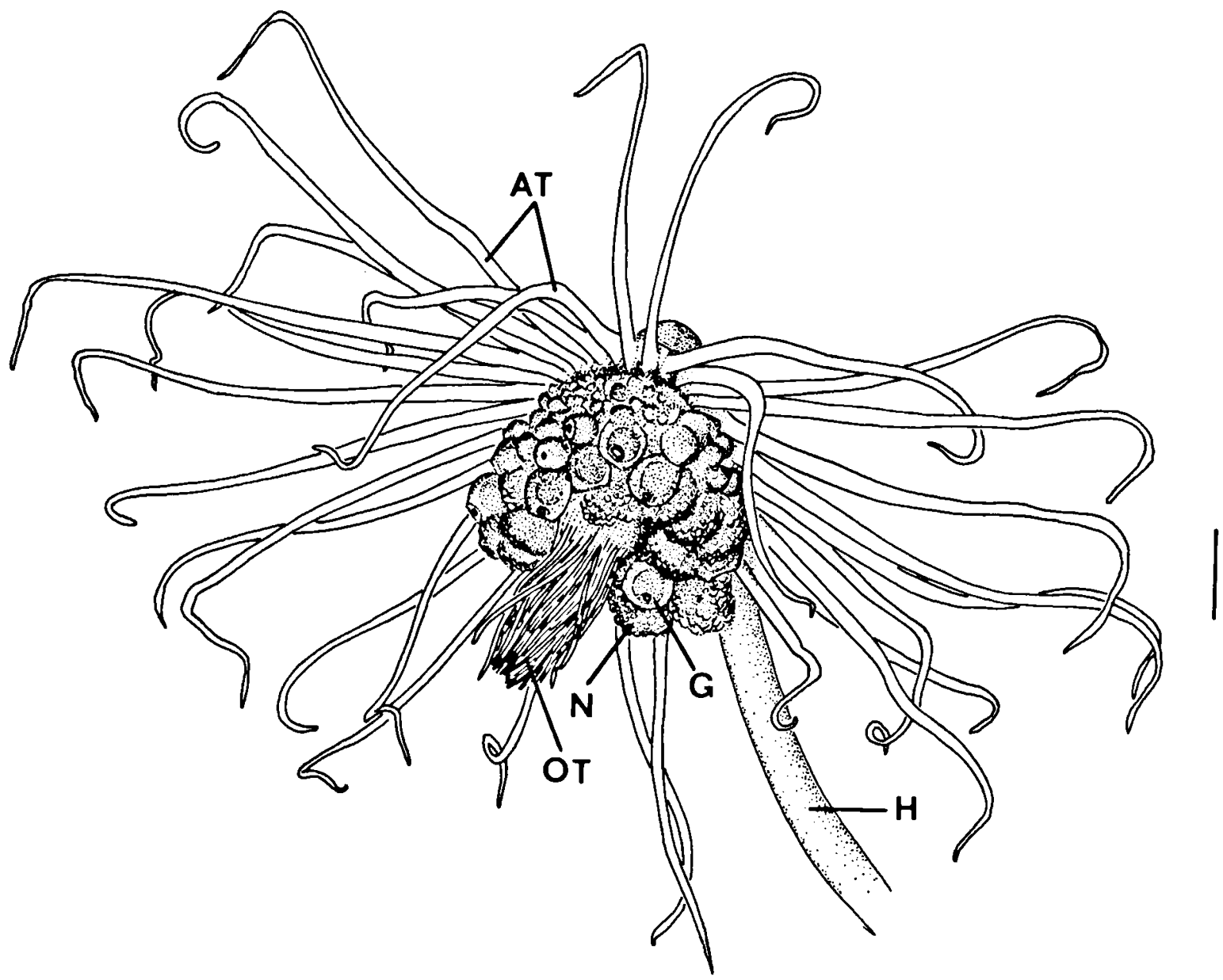

Fig. 1. Large size hydranth drawn from life. AT, aboral tentacles; G, gonophore (mature medusa); H, hydrocaulus; N, nematophore (palpon); OT, oral tentacles. Scale $2 \mathrm{~mm}$.

Coenenchyme growth occurs over the hydrocaulus without the development of the gorgonian axis skeleton. The stem of the hydranth was of uniform diameter except for two transverse constrictions; the stalk distal to the constrictions was slightly broader than average diameter. The hydrocaulus is surrounded by a smooth, membranous and naked perisarc. The stem is light yellow (Noo $A_{70}$ $\mathrm{M}_{10}$ ). On larger animals the distal limit of the perisarc next to the free coenosarc and the base of the hydranth possesses up to six transverse annulations. Exposed parts of the hydrocaulus may be overgrown with fleshy filamentous red algae. Hydrocaulus length appears to vary according to the length of the gorgonian axis skeleton. At the top of the projecting hydrocauli there are hydranths of various sizes (figs. 1 and 2). The coenosarc is a continuous sheet under the perisarc and possesses a central space filled with parenchyma and divided by complete or incomplete longitudinal gastrovascular canals (figs. 3A and 3B). The coenosarc is delicately striped parallel to the main axis of the stalk. Transverse sections of the hydrocaulus at $5 \mathrm{~mm}$ intervals showed that near the hydranth the central cavity is bordered with longitudinal endodermal ridges (fig. $3 \mathrm{~A}$ ). The ridges give rise to canals which increase in number and vary in diameter away from the hydranth (fig. 3B).

Living hydranths are white with an orange ring (Noo $\left.A_{80} M_{70}\right)$ around the mouth and a 


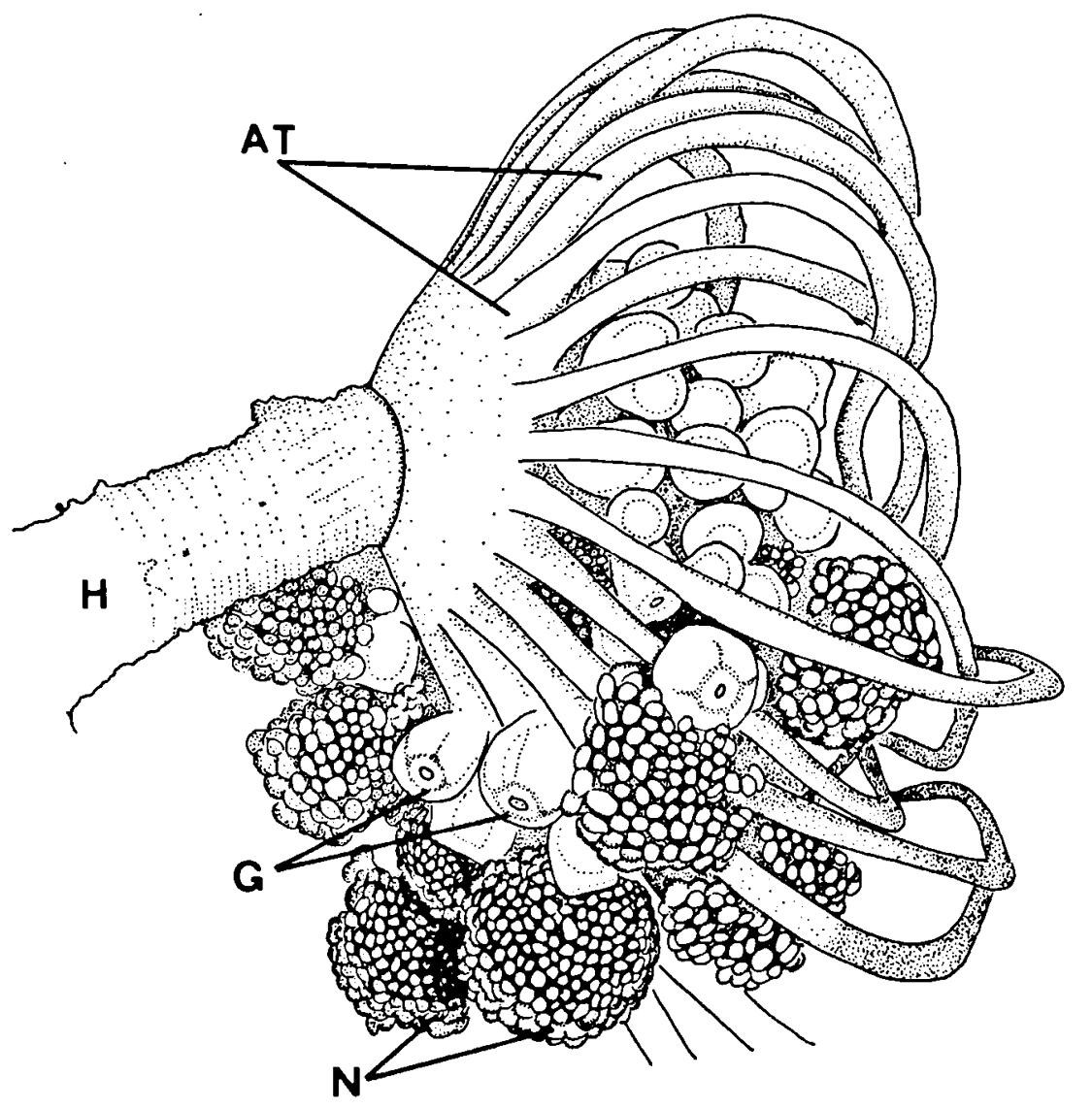

Fig. 2. Lateral aboral view of large size hydranth drawn from life. AT, aboral tentacles; $\mathrm{G}$, gonophore (mature medusae); $\mathrm{H}$, hydrocaulus; $\mathrm{N}$, nematophore (palpon). Scale $2 \mathrm{~mm}$.

reddish-brown ring ( $\left.\mathrm{N}^{20} \mathrm{~A}_{70} \mathrm{M}_{60}\right)$ around the base of the aboral tentacles. The junction between the stem and the trophosome is a constriction devoid of perisarc and is the point of flexing movements. At the base of the hydranth there is a circlet of evenly-spaced filamentous aboral tentacles which are flattened proximally, solid, pointed and whitish in color. Distally there is a crown of three or four concentric irregular circlets of tight, short, whitish, filamentous oral tentacles (fig. 1). The hypostome is cone-shaped, starting at the base of the aboral tentacles and narrowing at the mouth.

\section{GENERAL FEATURES OF GONOSOMES}

Medium-sized to large animals possess irregular circlets of gonosomes on the lower sur- face of the hypostome. The gonosomes on large animals are well developed in size and number, hanging among aboral tentacles (fig. 2). Their stalks are branched to the second order. The proximal branches give rise to the gonophores (medusae) and distal branches are defensive individuals (nematophores) armed with nematocysts (figs. 2 and 4). On young forms the gonosomes are few and reduced, with only nematophores. The nematophores are milky white and cauliflower-like, while gonophores are orange to red and bell-shaped in early stages (fig. 4).

The following characteristics refer to attached terminal maturing stages and to newly released medusae. Medusae are deep bellshaped (length slightly larger than diameter), transparent and without tentacles or tentacle 


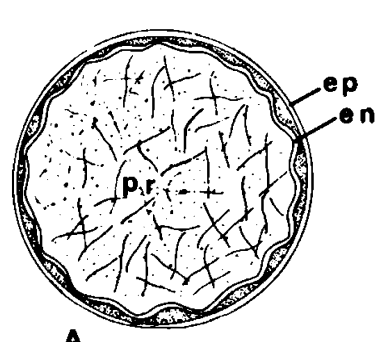

A $\mathbf{8}$

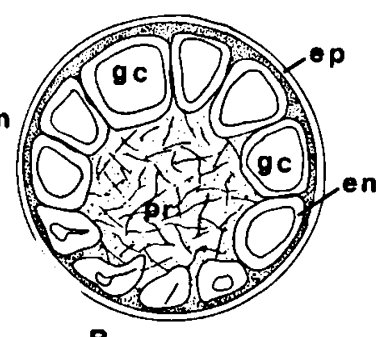

Fig. 3. Cross sections of the hydrocaulus of the largest polyp drawn from preserved specimen. A, distal hydrocaulus; B, proximal hydrocaulus; ep, epidermis; en, endodermis; gc, gastrovascular canal; pr, parenchyma. Same scale as fig. 4 .

buds. There are four radial canals and a ring canal dotted with orange to red pigment. The manubrium is as long as the umbrella or slightly shorter, dull and the color of the radial canals. There are no nematocyst tracts on the bell of the medusa. Hours before release, medusae show coordinated and variable contractions of the bells. The medusae are poor

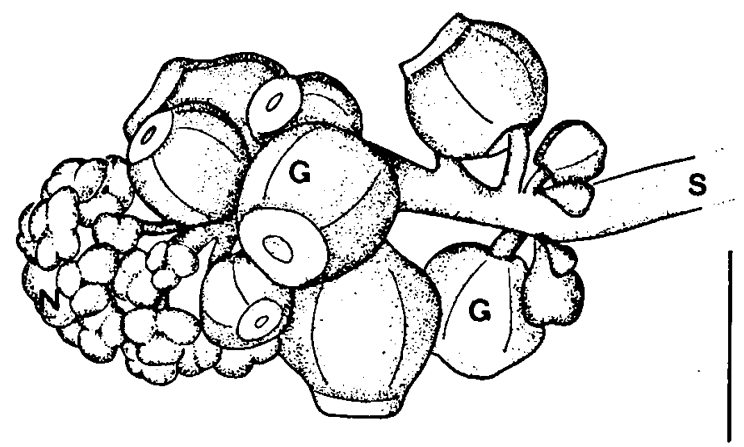

Fig. 4. Gonosome (cormidium) drawn from preserved specimen. S, stalk; G, gonophore (medusa); N, nematophore (palpon). Scale $1 \mathrm{~mm}$.

swimmers and have a tendency to remain on the bottom. We tried to maintain newly released medusae in small vials to which fresh plankton was added from time to time. They survived two days, never feeding, suggesting that the mouth did not open.

\section{NEMATOCYSTS}

The nematocysts are of three types (fig. 5), distributed as follows:
Oral tentacles:

- Large stenotele, $16.5 \times 11.0-13.0 \times 7.5$ $\mu \mathrm{m}$. Few.

- Small stenotele, $8.0 \times 6.0-7.5 \times 5.0 \mu \mathrm{m}$. Numerous. Capsule oval, butt about half of capsule length.

- Heterotrichous anisorhiza, $14.0 \times 7.5-12.5$ $\times 8.5 \mu \mathrm{m}$. Capsule subspherical. Rare.

Aboral tentacles:

- Large stenotele, $12.5 \times 11.0-11.0 \times 8.0$ $\mu \mathrm{m}$. Numerous.

- Small stenotele, $8.0 \times 6.0-7.0 \times 4.5 \mu \mathrm{m}$. Numerous. Capsule oval, butt about one third length of capsule.
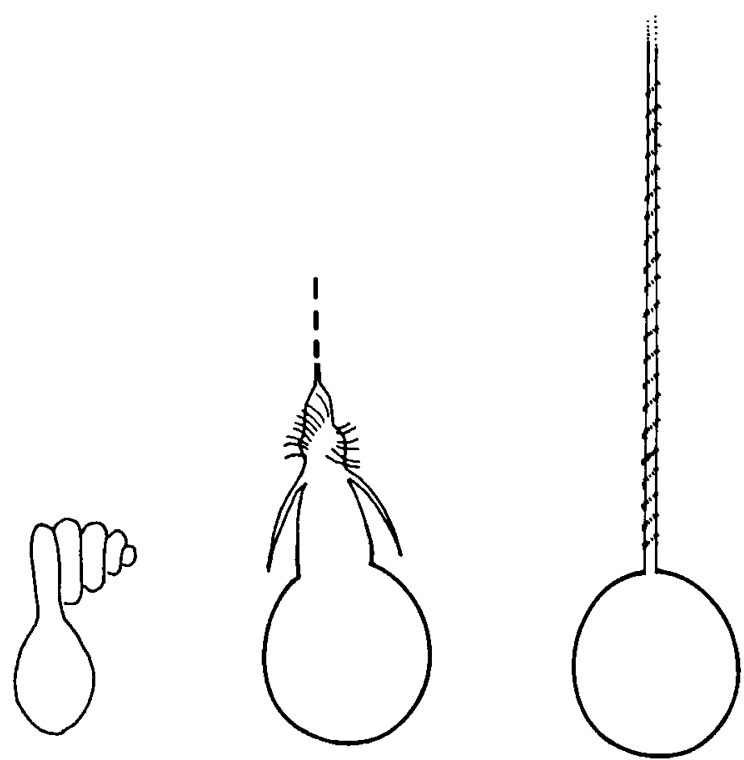

Fig. 5. Nematocysts, left to right: desmoneme, large stenotele and heterotrichous anisorhiza. Scale $10 \mu \mathrm{m}$.

- Heterotrichous anisorhiza, $18.5 \times 12.0$ $-14.0 \times 10.5 \mu \mathrm{m}$. Numerous. Capsule subspherical.

- Desmoneme, $8.0 \times 5.5-6.5 \times 4.0 \mu \mathrm{m}$. Numerous. Capsule oval, discharged thread with five coils.

Nematophore:

- Stenotele, $15.0 \times 13.0-13.5 \times 12.0 \mu \mathrm{m}$. Few. Capsule oval, butt almost half length of capsule. 


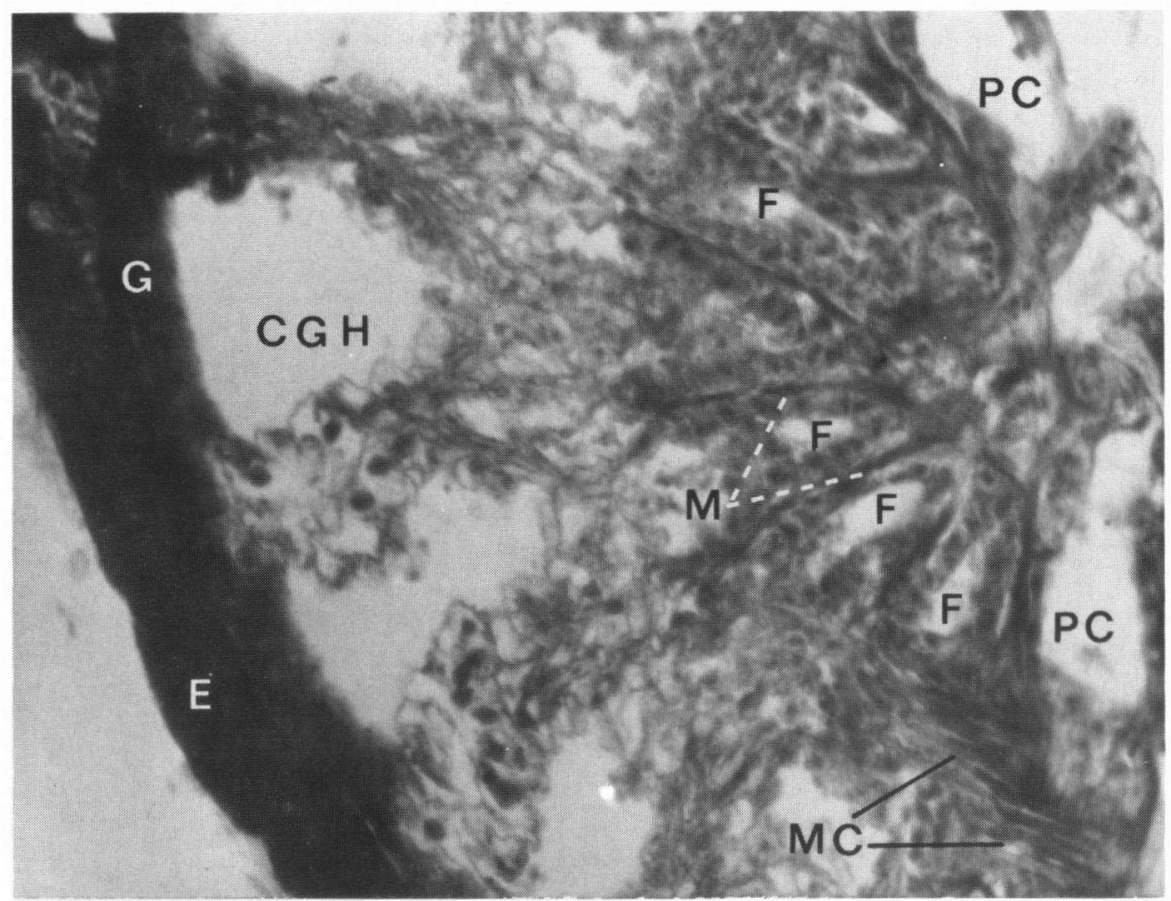

Fig. 6. Photomicrograph of diagonal section through base of hydranth and distal part of hydrocaulus to show the fenestrae. E, epidermis; F, fenestrae; G, gastrodermis; CGH, gastrovascular cavity of hydrocaulus; $M$, mesoglea; $M C$, myocytes; PC, parenchymatous cushion; $(100 \times)$.

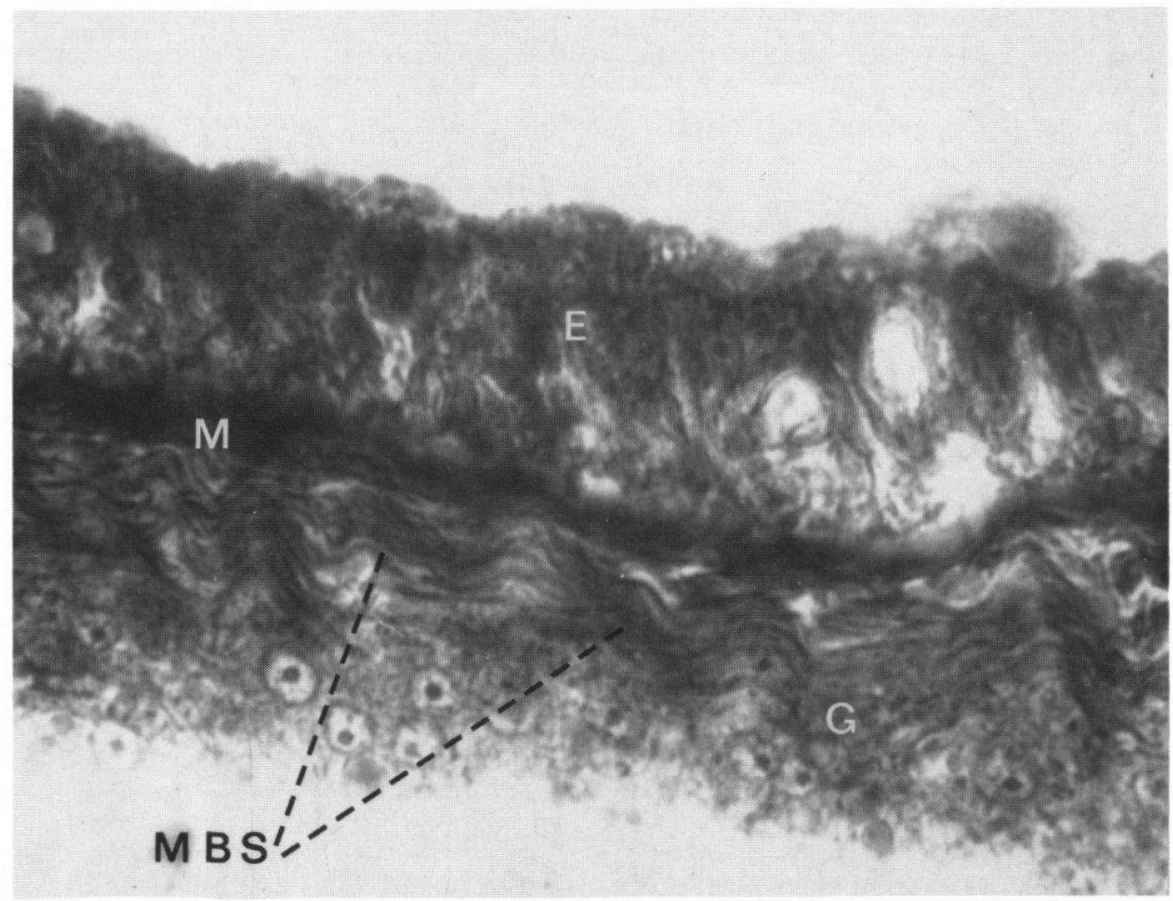

Fig. 7. Photomicrograph of hydranth body wall sectioned at the base to show the endodermal sphincter. E, epidermis; G, gastrodermis; M, mesoglea; MBS, myocyte bundles of sphincter; $(400 \times)$. 


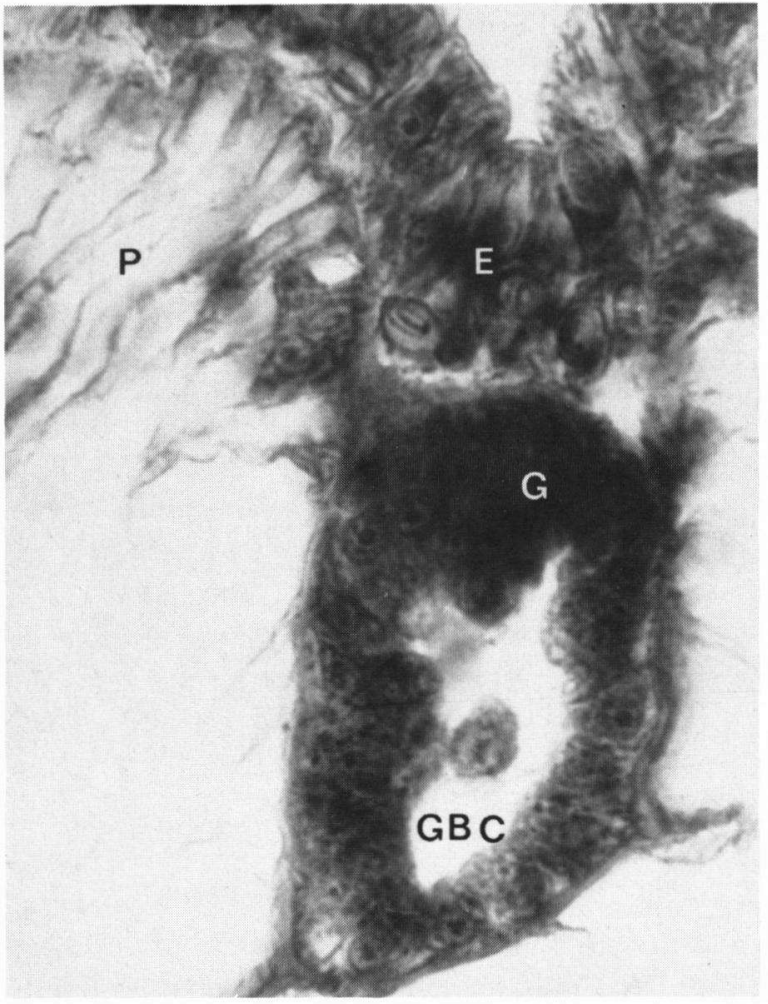

Fig. 8. Photomicrograph of hydranth body wall sectioned at the base of aboral tentacle crown to show the endodermis canals. E, epidermis; G, gastrodermis; GBC, gastrodermal blind canals; $P$, parenchyma; $(334 \times)$.

- Heterotrichous anisorhiza, $14.0 \times 11.0$ $-12.0 \times 10.0 \mu \mathrm{m}$. Numerous. Capsule subspherical.

\section{MICROSCOPIC ANATOMY}

Transverse sections of hydrocauli showed that the longitudinal canals are only endodermal and the central cavity is filled with parenchyma (fig. 3). The coenosarc epidermis possesses scattered nematocysts. Myocytes are almost absent in the epidermis and gastrodermis, but increase closer to the base of the hydranth. At the neck region myocytes are rather common, forming a mesh mainly in the epidermis; epidermal secretory cells are replaced by tall supporting cells and nematoblasts. The amount of mesoglea also increases. Invested on the most

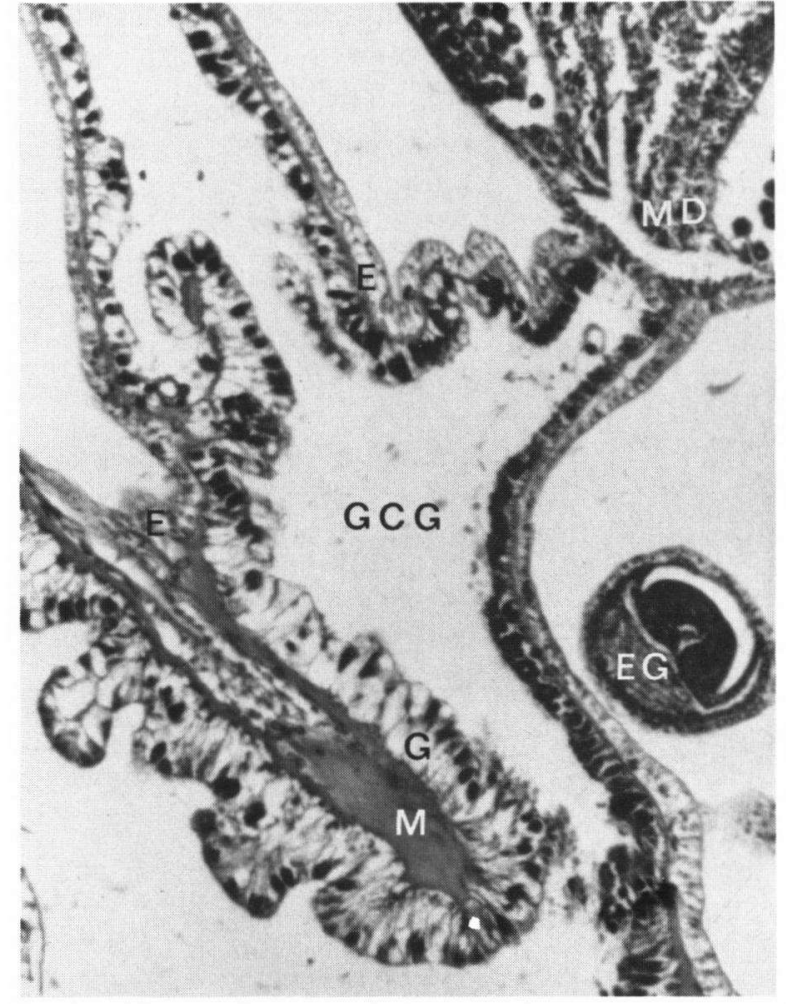

Fig. 9. Photomicrograph of hydranth body wall sectioned above the aboral tentacle crown to show the gonosome stalk. E, epidermis; EG, early gonophore; G, gastrodermis; GCG, gastrovascular cavity of gonosome; $M$, mesoglea; MD, medusa; $(50 \times)$.

distal part of the neck there is a short cone of endodermis, the wall of which is interrupted by longitudinal openings (fenestrae) that connect the internal cavities of the hydranth with the stem (fig. 6). Bordering these slits there is a thickening of the mesoglea and there are clusters of myocytes (fig. 6).

In the base of the hydranth and just distal to the constriction region are numerous myocytes. Radial myocytes in the epidermis become delicate radial bundles upon contraction, and endodermis myocytes form a strong circular sphincter (fig. 7). The fenestrated cone of endodermis progresses as a cylinder that enlarges to a funnel merging with the polyp wall. The funnel and the cylinder make up the floor of the gastrovascular cavity. The wall of the hypostome, up to the mouth, makes up the roof 
of the gastrovascular cavity. Beneath the floor is a closed space that circles the base of the hydranth, the parenchymatous cushion (fig. 6). Parenchyma of this cushion is evenly separated from gastrodermis by mesoglea. Gastrodermal folds occur on the floor of the gastrovascular cavity, the crests of which represent the regular inward progress of the proximal tentacles. Peripheral blind canals radiate for a short distance between the aboral tentacles (fig. 8). The enclosed parenchyma of the cushion is separated from the parenchyma of the tentacles by a thin lamella. Some endodermis cells within the tentacles are myocytes placed at right angles to the main axis of the tentacle. Epidermal myocytes of the tentacles are parallel to the main axis. The gastrodermis of the hypostome is much crested and uneven. The epidermis is also crested in a regular radial pattern unrelated to the patterns mentioned above.

The oral tentacles are simple outward projections of the hypostome body wall, filled with parenchyma which is separated from the gastrodermis by a thin lamella. The gonosomes are hollow body wall outgrowths (figs. 9 and 10). In the endodermis of nematophores secretory cells are less abundant than in other regions of the gonosome (fig. 11). Hydranths are dioecious, without dimorphism of gonophores. Male medusae were recognized as free-swimming stages. The manubrium epidermis of mature male medusae was filled with evenly distributed spermatozoans. We found few remnants of early stage male germ cells. Mature female medusae remain attached. Oogonia occur at the surface layer and oocytes occur in the deeper layer of the manubrium epidermis.

\section{DISCUSSION}

The external anatomy of the trophosome of Serehyba sanctisebastiani agrees with the diagnostic features of the hydrozoan athecate family Tubulariidae (Kühn, 1913; Kramp, 1949; Rees, 1957; Naumov, 1960; Brinckmann-Voss, 1970; Millard, 1975; Petersen, 1979): hydranth with one whorl of filiform aboral tentacles and one whorl of filiform oral tentacles; the gonosomes develop from the surface of the hypostome between the two whorls of tentacles; erect stem with firm perisarc which reaches to the base of the hydranth body. The histology of the trophosome combines most features of tubulariid polyps with an elaborate structure of the stem by the presence of separate longitudinal endodermal canals within the parenchyma, a feature which is always found in large size solitary hydranths of the family Corymorphidae Allman, 1867 (subfamilies Corymorphinae and Branchiocerianthinae Rees, 1957), and which has been retained by the solitary tubulariid Zyzzyzus solitarius (Warren, 1906). Millard (1975) supposed that Zyzzyzus represents an intermediate stage between early Corymorphidae and Tubulariidae. Millard agreed with Rees (1957) that the Tubulariidae evolved from members of the Corymorphidae. Grönberg (1897) found separate endodermal canals in distal parts of the hydrocaulus of the solitary Tubularia indivisa Linnaeus, 1758. Watson (1980) described a new genus and species of a rare colonial tubulariid, Ralpharia magnifica, with longitudinal canals within the distal hydrocaulus stem. The colony structure of Ralpharia magnifica and of $S$. sanctisebastiani probably refutes the assumption that the elaborate structure of separate endodermal canals is a feature of solitary forms only, being an acquisition some solitary Tubulariidae share with their Corymorphidae ancestors. It follows that in the hydranth of $S$. sanctisebastiani the presence of radial canals immediately above the parenchymatous cushion may not be related to an elaboration of solitary large-sized forms derived from the Corymorphidae. Rees (1957) emphasized the presence of radial canals to devise the evolutionary lineage of solitary hydranths starting with the Corymorphidae; he drew a homology between the radial canals of the solitary polyps of Branchiocerianthus imperator Miyajima, 1900, with those of Tubularia indivisa to explain that the float of Pelagohydra mirabilis Dendy, 1902 (family Margelopsidae Uchida, 1927 ) is the basal half of a solitary pelagic hydranth. 


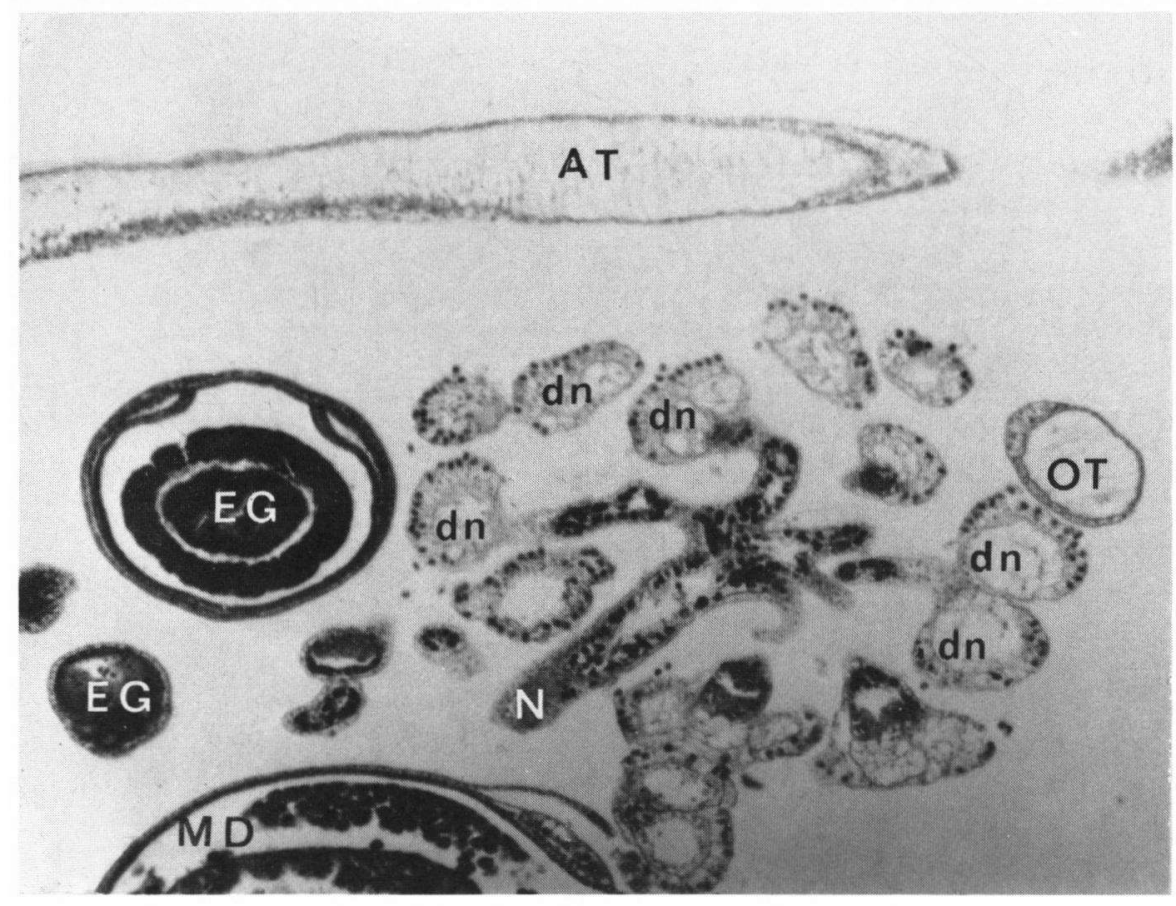

Fig. 10. Photomicrograph of gonosome sectioned along oral-aboral axis of trophosome: right side is the proximal and left side is the distal part of one gonosome. AT, aboral tentacle (sectioned along longest axis); dn, distal part of nematophore; EG, early gonophore; $\mathrm{MD}$, medusa; $\mathrm{N}$, nematophore; $\mathrm{OT}$, oral tentacle (sectioned along transversal axis); $(40 \times)$.

The structure of the gonosomes of $S$. sanctisebastiani is unique among tubulariids possessing "modular" construction (sensu Chapman \& Stebbing, 1980). To understand their organization we draw an analogy with the siphosome of some Siphonophora: the gonosome is a "cormidium" including a "gonodendron" and a "siphon"; the gonophores are detached reduced anthomedusae and the nematophore ( = "siphon") is a "palpon" (Garstang, 1946). In comparison with the cormidium of Siphonophora, the order of gonodendron and siphon is inverted: gonodendron is proximal to palpon. We do not think that the gonosomes of $S$. sanctisebastiani are comparable with the blastostyles of some other athecate hydrozoans (e.g. Myriothela M. Sars, 1815). The nematophores of $S$. sanctisebastiani differ in their structure and development from the tentacles of the blastostyles of Myriothela. Manton (1940) observed that the lumen of the tentacles of the blastostyles of Myriothela penola Manton, 1940 and of Myriothela capensis Manton, 1940 "does not communicate with that of the blastostyle, a layer of mesoglea, covered on both sides by endoderm, spanning the tentacle base".

The gonosomes of $S$. sanctisebastiani are more complex than the gonophore-producing blastostyles of other tubulariids. The fact that the nematophores differentiate earlier than the gonophores during development (see observations of living material below) shows the different nature of the gonosomes and blastostyles.

Among the genera of Tubulariidae, hydroids with fixed gonophores ( = fixed sporosacs) are considered to be distinct from hydroids with free medusae (Rees, 1957; Naumov, 1960; Brinckmann-Voss, 1970; Millard, 1975). Fixed sporosacs are all degenerate medusoid stages, including the eumedusoid, cryptomedusoid, heteromedusoid and styloid stages (originally defined by Kühn, 1913 and retained by Hyman, 1940; Naumov, 1960; Campbell, 1974; Millard, 1975). Brinckmann-Voss (1970) 


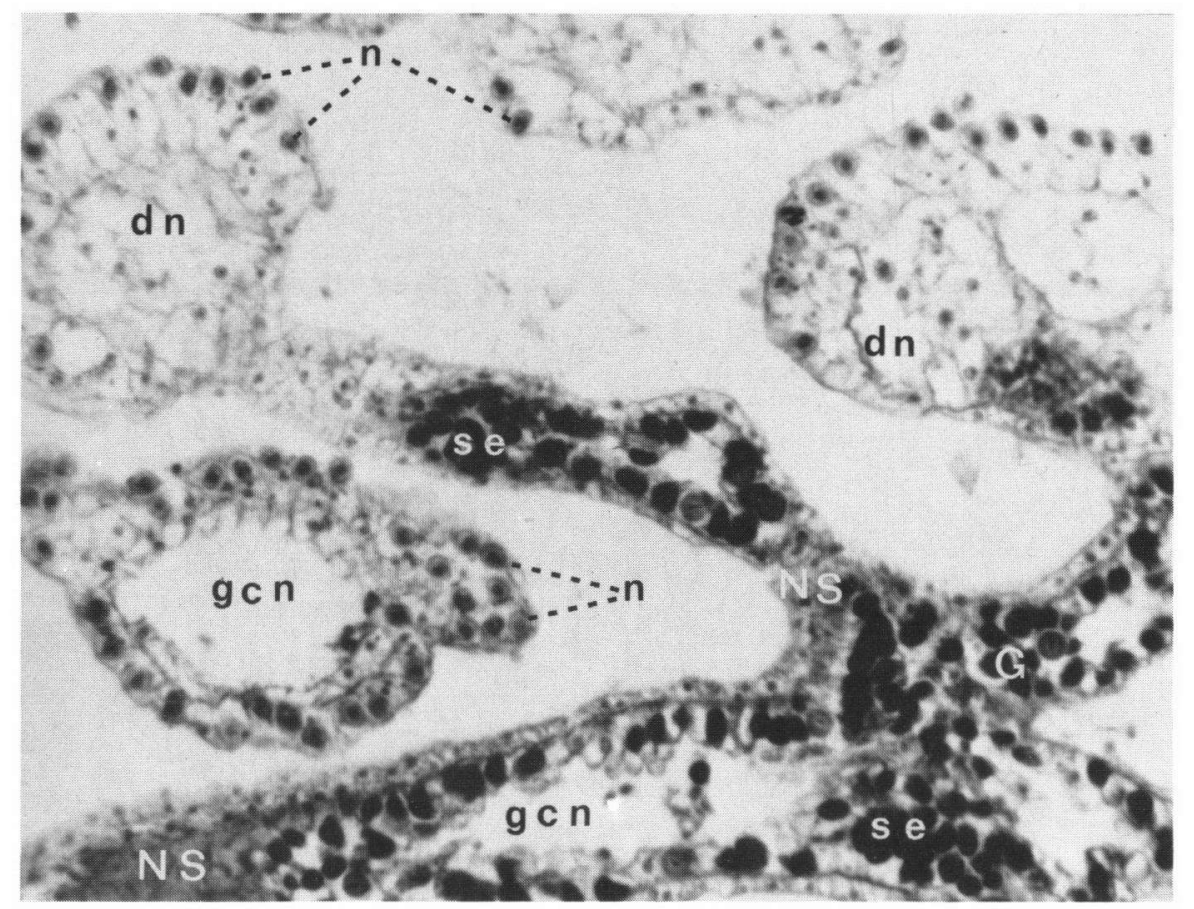

Fig. 11. Photomicrograph of part of nematophore shown in fig. 10. Note the simple architecture and lack of secretory cells in the endodermis of the distal parts of the nematophore; dn, distal parts of nematophores; G, gastrodermis; gcn, gastrovascular cavity of nematophore; $n$, nematocysts; NS, nematophore stalk; se, secretory cells of endodermis; $(400 \times)$.

and Millard (1975) distinguished the genera Zyzzyzus Stechow, 1921 and Tubularia Linnaeus, 1758 , with fixed sporosacs, from the genera $E c$ topleura L. Agassiz, 1862 and Hybocodon L. Agassiz, 1862, with free medusae.

Watson (1980) described a fifth genus, Ralpharia, with free-swimming reduced medusae (four rudimentary marginal tentacles and no mouth) of the symmetrical type. The main diagnostic character which distinguishes Ralpharia from Ectopleura is the absence of nematocyst tracks on the exumbrella of the medusa (Watson, 1980: 54).

We agree with Petersen (1979) that the hydroid stage of tubulariids offers good systematic characteristics on which distinction among genera can be based. Therefore, the genus level classification of tubulariid polyps includes the solitary Zyzzyzus with a thin perisarc and tuber-like attachment of hydrocaulus, the solitary Tubularia with a firm perisarc and producing either free medusae (genus Hybocodon L.
Agassiz, 1862) or with fixed gonophores of the asymmetrical type, and the colonial Ectopleura with a firm perisarc and producing either free medusae (genus Ectopleura L. Aggassiz, 1862) or with fixed gonophores of the symmetrical type. Serehyba sanctisebastiani $\mathrm{n}$. gen., n. sp. represents a colonial tubulariid with a firm perisarc and with the gonosome in cormidium.

\section{BIOLOGICAL NOTES}

In the laboratory we observed that from time to time the hydranths of Serehyba sanctisebastiani regressed and desintegrated at the level of the margin of the perisarc of the hydrocauli, followed by replacement by regenerating buds (figs. 12A, $B$ and $C$ ). The bud regenerated a hydranth in only one day in the same way as in the related Corymorpha palma Torrey, 1902 (see Torrey, 1910) and C. nutans Sars, 1835 (see Svoboda, 1973). We also observed a doubleregenerating bud and the formation of two new 


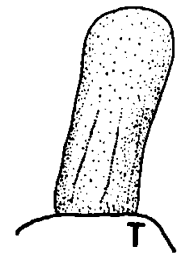

A

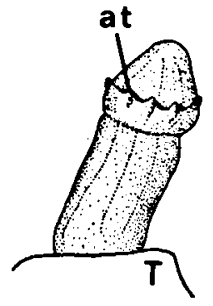

B

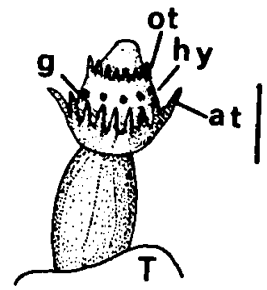

C
Fig. 12. Regenerating stages drawn from life at $24^{\circ} \mathrm{C}$. A, early regeneration bud 53 hours after purposeful amputation; B, early differentiation of regenerating fields of hydranth and hydrocaulus 72 hours after amputation; C, early differentiation of oral tentacles and budding of gonosomes $\mathbf{8 0}$ hours after amputation; at, aboral tentacles; g, early gonosome bud; hy, hypostome; ot, oral tentacles; $\mathrm{T}$, gorgonian branch tip. Scale $1 \mathrm{~mm}$.

hydranths at the site of purposeful amputation of a polyp. The gonosome development of regenerating individuals stopped with differentiation of the nematophores and incomplete budding of gonophores in the shape of fingerlike blastostyles. The regeneration and replacement of the hydranths through autolyses may be a histophysiological rejuvenation of the hydranth (Tardent, 1963) or a growth stimulus of the hydrocaulus (Hughes, 1983).

Close relationships between tubulariids and their invertebrate hosts have been noted for Hybocodon unicus (Browne, 1902), with hydrorhiza branching within the sponge Hymeniacedon perlevis (Montagu) (see Millard, 1975), and Zyzzyzus solitarius (Warren, 1906) from South Africa, with fleshy storage tubers and supporting rootlets within silicious sponges (Warren, 1906; Millard, 1975). There is at least one record of a solitary tubulariid, Tubularia multitentaculata Fraser, 1938, living on unspecified gorgonians off the coast of Lower California (Fraser, 1938). Ralpharia magnifica presents a tubular hydrorhiza embedded in the sheet-like mass of Parerythropodium membranaceum Kükenthal, 1906 (Anthozoa, Alcyonacea) and the actinulae are able to grow pedicels which penetrate the alcyonacean (Watson, 1980). Although we do not yet know the conditions and timing that pertain to the association between $S$. sanctisebastiani and the gorgonian, there are possible benefits to both species: Lophogorgia provides a strong support for the hydrozoan, which grows its hydrocaulus very fast; and linear extension of the smooth perisarc of $S$. sanctisebastiani allows gorgonian coenenchyme growth over additional substratum (a trend known for other gorgonians, cf. Kinzie, 1970; Silveira \& Van 't Hof, 1977), which would hasten the usually slow development of the octocoral.

\section{ACKNOWLEDGEMENTS}

We are grateful to Dr. S. Stancyk for his critical reviews of the manuscript and helpful suggestions. We thank Dr. E. Schlenz for helping with the German literature. Furthermore, we are indebted to Dr. F. M. Bayer and Mr. C. B. Castro for classification of the gorgonian coral.

\section{LITERATURE}

Allman, G. J., 1864. On the construction and limitation of genera among the Hydroida. Ann. Mag. nat. Hist., (3) 13: 345-380.

BAYER, F. M., 1961. The shallow-water Octocorallia of the West Indian region. A manual for marine biologists. Stud. Fauna Curaçao, 12 (55): [i-viii], 1-373, pls. I-XXVII.

Brinckmann-Voss, A., 1970. Anthomedusae/Athecatae (Hydrozoa, Cnidaria) of the Mediterranean, I. Capitata. Fauna Flora Golfo Napoli, 39: [i-iii], 1-96, pls. I-XI.

Campbell, R. D., 1974. Cnidaria. In: A. C. Giese \& J. S. PeArse eds., Reproduction of marine invertebrates, I. Acoelomate and pseudocoelomate metazoans: 133-199 (Academic Press, New York \& London).

Chapman, G. A. R. D. Stebbing, 1980. The modular habit a recurring strategy. In: $P$. TARDENT \& $R$. TARDENT eds., Development and cellular biology of coelenterates: 157-162 (Elsevier/North Holland Biomedical Press, Amsterdam).

Fraser, C. M., 1938. Hydroids of the 1934 Allan Hancock Pacific Expedition. Allan Hancock Pacif. Exped., 4 (1): 1-105.

Garstang, W., 1946. The morphology and relations of the Siphonophora. Quart. J. microsc. Sci., 87: 103-193.

Grönberg, G., 1897. Beiträge zur Kenntniss der Gattung Tubularia. Zool. Jb., (Anat.) 11 (1): 61-76, pls. 4-5.

Hughes, R. G., 1983. The life-history of Tubularia indivisa (Hydrozoa: Tubulariidae) with observations 
on the status of T. ceratogyne. J. mar. biol. Ass. U.K., 63 (2): 467-479.

Hyman, L. H., 1940. The invertebrates: Protozoa through Ctenophora, 1: i-x, 1-726 (MacGrawHill, New York).

Kinzie, R. A., 1970. The ecology of the gorgonians (Cnidaria, Octocorallia) of Discovery Bay, Jamaica: 1-107 (Ph. D. thesis, Yale University).

Kramp, P. L., 1949. Origin of the hydroid family Corymorphidae. Vidensk. Meddr. dansk naturh. Foren., 111: 183-215.

KüHN, A., 1913. Entwicklungsgeschichte und Verwandtschaftsbeziehungen der Hydrozoen, I. Die $\mathrm{Hy}$ droiden. Ergebn. Fortschr. Zool., 4: 1-284.

Küppers, H., 1979. Atlas de los colores. Translation by Feliz de la Fuente: 1-161 (Editorial Blume, Barcelona).

Mahoney, R., 1973. Laboratory techniques in zoology: 269-270 (Butterworth \& Co., London).

Manton, S. M., 1940. On two new species of the hydroid Myriothela. Scient. Rep. Br. Grahamld. Exped., 1: 255-293.

Millard, N. A. H., 1975. Monograph on the Hydroida of southern Africa. Ann. S. Afr. Mus., 68: 1-513.

Naumov, D. V., 1960. Hydroids and Hydromedusae of the marine, brackish and freshwater basins of the U.S.S.R. Opred. Faune SSSR, 70: 1-585. (In Russian; translated by Israel Program for Scientific Translations, 1969.)

Petersen, K. W., 1979. Coloniality in Hydrozoa. In: G. E. LARWood \& B. R. Rosen eds., Biology and systematics of colonial organisms: 105-140 (Academic Press, London).
ReEs, W. J., 1957. Evolutionary trends in the classification of capitate hydroids and medusae. Bull. $\mathrm{Br}$. Mus. nat. Hist. Zool., 4 (9): 453-534, pls. 12-13.

Silveira, F. Lang da \& T. van 't Hof, 1977. Regeneration in the gorgonian Plexaura flexuosa (Cnidaria, Octocorallia). Bijdr. Dierk., 47 (1): 98-108.

Svoboda, A., 1973. Underwater observations on the life cycle of Corymorpha nutans (Hydrozoa). Helgoländer wiss. Meeresunters., 24: 145-150.

TARDent, P., 1963. Regeneration in the Hydrozoa. Biol. Rev., 38 (3): 293-333.

Torrey, H. B., 1910. Biological studies on Corymorpha, III. Regeneration of hydranth and holdfast. Univ. Calif. Publs. Zool., 6 (10): 205-221.

Vannuaı, M., 1957. On Brazilian hydromedusae and their distribution in relation to different water masses. Bolm. Inst. Oceanogr. S. Paulo, 7 (1-2): 40-41.

WArren, E., 1906. On Tubularia solitaria sp. nov., a hydroid from the Natal Coast. Ann. Natal. Mus., 1: 83-96, pls. X-XI.

Watson, J. E., 1980. The identity of two tubularian hydroids from Australia with a description and observations on the reproduction of Ralpharia magnifica gen. et sp. nov. Mem. natn. Mus. Vict., 41: 53-63.

Weill, R., 1937. Contribution à l'étude des Pteronemida (Hydrozoaires). Le cnidome de Cladocoryne floccosa Rotsch et son interprétation (d'après les documents laissés par feu Maurice Philbert). Bull. Inst. océanogr. Monaco, 719: 1-11. 